\title{
The Cultural Politics of Dan Quayle AND Mike PenCe
}

\author{
STEVE SANDERS ${ }^{*}$
}

\section{INTRODUCTION}

The Gallup polling organization classifies Indiana as a "pink" state, rather than a "red" state, meaning it leans Republican but is not solidly in the GOP column. ${ }^{1}$ After all, in recent years Indiana has sent Democrats like Evan Bayh and Joe Donnelly to the United States Senate. ${ }^{2}$ From 1989 through 2004, the state had a succession of Democratic governors. ${ }^{3}$ And in the 2008 presidential election, the state was carried by Barack Obama. ${ }^{4}$ As the headline on a Boston Globe political story put it during the 2016 presidential primaries, "Indiana is not the solid red state everyone thinks it is."

Yet, if an image of Indiana persists in many people's minds as a bastion of social conservatism and tradition, that image likely has been shaped in part by the two most recent vice presidents the Hoosier state has sent to Washington: Dan Quayle and Mike Pence.

In selecting their running mates, major party presidential candidates typically look for someone with strengths or experience that the person at the top of the ticket lacks. Both Quayle and Pence were chosen, to a large degree, because they were seen as effective and important ambassadors to social and religious conservatives - a group that was not the natural constituency of their senior running mates, George H.W. Bush and Donald Trump, respectively. ${ }^{6}$ Barring

* Associate Professor, Indiana University Bloomington Maurer School of Law.

1. Jeffrey M. Jones, Red States Outnumber Blue for First Time in Gallup Tracking, GaLluP (Feb. 3, 2016), https://news.gallup.com/poll/188969/red-states-outnumber-blue-first-time-galluptracking.aspx [https://perma.cc/M7PM-PZW4].

2. Indiana Governor Evan Bayh, IND. HIST. BuREAU, https://www.in.gov/history/2708.htm [https://perma.cc/8VAW-VREV] (last visited Nov. 8, 2018); About Joe, Joe Donnelly U.S. SENATOR FOR IND., https://www.donnelly.senate.gov/about/joe [https://perma.cc/W2Z4-DGW3] (last visited Nov. 8, 2018).

3. Indiana: Past Governors Bios, NAT'L GOVERnORS ASS'N, https://classic.nga.org/cms/ home/governors/past-governors-bios/page_indiana.html [https://perma.cc/CPS7-Q44V] (last visited Nov. 8, 2018).

4. Election Results 2008, N.Y. TimES (Dec. 9, 2008), https://www.nytimes.com/elections/ 2008/results/states/indiana.html [https://perma.cc/B2NB-7BKV].

5. James Pindell, Indiana Is Not the Solid Red State Everyone Thinks It Is, Bos. GLoBE (Apr. 28, 2016), https://www.bostonglobe.com/news/politics/2016/04/28/indiana-not-solid-redstate-everyone-thinks/nEMg48iGgCrkNU8dPgFKbN/story.html [https://perma.cc/6WZY-8PNM].

6. Chris Cillizza, 5 Reasons Mike Pence Makes a Lot of Sense as Donald Trump's Vice President, Wash. Post (July 14, 2016), https://www.washingtonpost.com/news/the-fix/wp/ 2016/07/14/5-reasons-why-mike-pence-makes-a-lot-of-sense-as-donald-trumps-vicepresident/?utm_term=.34f69fbc53b4 [https://perma.cc/2PLZ-9RRF]; Peter Osterlund \& Donald L. Rheem, Quayle: Wide Appeal but Untried on National Stage, Christian SCI. Monitor (Aug. 18, 
some event that elevates Pence to the presidency, this is how both Quayle and Pence are likely to be remembered by history: As great favorites, even paragons, of the religious right, and as loyal political subalterns whose job was to carry the torch for "family values," opposition to abortion and LGBT rights, and a greater role for religion in American public life.

\section{DAN QUAYLE}

James Danforth Quayle was born in Indianapolis and was educated at DePauw University and what is known today as the Indiana University Robert $\mathrm{H}$. McKinney School of Law. ${ }^{7}$ His maternal grandfather was the powerful-and quite conservative - newspaper publisher Eugene Pulliam, who once remarked, "I've never been interested in the money I make but the influence we have." In 1976, two years after earning his law degree, Quayle began his political career when he was elected to Congress from Indiana's Fourth District.'

In 1980, running on the slogan "a new generation of leadership," " Quayle, at age 33, became the youngest person ever elected to the Senate from Indiana, defeating legendary three-term incumbent Democrat and national liberal standard bearer Birch Bayh. ${ }^{11}$ Quayle's victory was part of the same Republican wave election that ushered Ronald Reagan into the White House. ${ }^{12}$ Making Indiana political history again, Quayle was re-elected to the Senate in 1986 with the largest margin ever achieved to that date by a candidate in a statewide Indiana race. ${ }^{13}$

Two years later, Quayle was chosen by George H.W. Bush as his vicepresidential running mate. ${ }^{14}$ The choice, though surprising because of Quayle's youth and relative inexperience, made a certain amount of sense. ${ }^{15}$ Quayle was seen as a young, Midwestern, outspoken conservative who would complement the

1988), https://www.csmonitor.com/1988/0818/aquay.html [https://perma.cc/VRQ7-A274].

7. Biography, Dan QuaYle: 44Th ViCe President of U.S., 1989-1993, http://www. vicepresidentdanquayle.com/biography.html [https://perma.cc/TMF8-ET37] (last visited Mar. 3, 2019) [hereinafter Biography of Dan Quayle].

8. Eleanor Randolph, Family Paper Deserves Credit on Quayle Story, CHI. TRIB. (Aug. 28, 1988), http://www.chicagotribune.com/news/ct-xpm-1988-08-28-8801260382-story.html [perma.cc/4K9L-P9EV].

9. Biography of Dan Quayle, supra note 7.

10. Osterlund \& Rheem, supra note 6.

11. Id.

12. Id.

13. Id.

14. Phil McCombs et al., The Day the Ticket Came Together, Wash. Post (Aug. 17, 1988), https://www.washingtonpost.com/archive/lifestyle/1988/08/17/the-day-the-ticket-cametogether/a02a8afd-236a-4d56-a9b6-f3 12a74a604c/?utm_term=.bdc751b56d07 [https:perma.cc/UG6A-C4V2].

15. Id. 
older, patrician, and politically more moderate Bush. ${ }^{16}$

The party's social and religious conservatives embraced the partnership. ${ }^{17}$ As the Washington Post reported, "Sen. Dan Quayle's advent as George Bush's vice presidential pick had conservatives beside themselves with joy . . ." ${ }^{18} \mathrm{New}$ Hampshire Republican Sen. Gordon J. Humphrey described himself as "[d]elighted, elated and greatly relieved" after "a long battle" at the GOP convention in New Orleans "threatened to lead dissident delegates in a floor fight if Bush's choice wasn't conservative enough." "Dan Quayle is the ultimate candidate," enthused the Rev. Jerry Falwell, head of the powerful religious conservative organization Moral Majority. ${ }^{20}$ "He is conservative. He is supportive of the prolife movement. Articulate. Young. He brings to the ticket what a [Robert] Dole and [Jack] Kemp would jointly — appeal to the Midwest, and to the religious conservatives."21 “[P]lus," Falwell gushed, "he's handsome!"22

Interestingly, earlier in his political career, Quayle wasn't known as the kind of fire-breathing conservative spokesman he would become. In a study of Quayle's service in the House and Senate, political scientist Richard Fenno described Quayle's attitude during his 1980 Senate campaign toward the issues of the "religious New Right" as "arms-length." 23

Although Quayle chafed at what he called the "awkward job" of the United States vice presidency ("You don't have your own agenda," he said. "Your agenda is the president's agenda."), ${ }^{24}$ he seemed happy to embrace his assigned role as Bush's most important liaison to his party's social and religious conservatives. As political writers David Broder and Bob Woodward reported, "[o]n the Republican political circuit, Quayle is almost constantly in demand." 25

In his most famous - many would say infamous - defense of "family values," Quayle tangled with television character Murphy Brown, the fictional investigative journalist and news anchor portrayed by Candace Bergen. In the show's 1991-92 season, Murphy Brown became pregnant. When the baby's father made clear he was not interested in being a parent, Murphy Brown chose to have the child and raise it alone.

In a speech to the Commonwealth Club of California in May 1992, in the midst of the Bush/Quayle re-election campaign, Quayle argued that "marriage is a moral issue that requires cultural consensus"; that "[b]earing babies

16. Id.

17. Id.

18. Id.

19. Id.

20. Id.

21. Id.

22. Id.

23. Richard F. Fenno, Jr., The Making of a Senator: Dan Quayle 17 (1989).

24. David S. Broder \& Bob Woodward, The Man Who Would Be President: Dan QUAYLE 90 (1992).

25. Id. at 103 . 
irresponsibly is, simply, wrong"; and that "[f]ailing to support children one has fathered is wrong. We must be unequivocal about this." ${ }^{26}$ Then he stepped into the popular-culture fray: "It doesn't help matters when prime time TV has Murphy Brown - a character who supposedly epitomizes today's intelligent, highly paid, professional woman - mocking the importance of fathers, by bearing a child alone, and calling it just another 'lifestyle choice."'27

Quayle's assault on Murphy Brown caused an immediate "uproar" and has been remembered as the opening salvo in "an early skirmish in the culture war." 28 Murphy Brown fired back in her TV persona:

While some might argue that attacking my status as a single mother was nothing more than a cynical bit of election-year posturing, I'd prefer to give the vice president the benefit of the doubt. These are difficult times for our country, and in searching for the causes of our social ills, we could choose to blame the media, or the Congress, or an administration that's been in power for 12 years. Or we could blame me. And while I will admit that my inability to balance a checkbook may have had something to do with the collapse of the savings and loan industry, I doubt that my status as a single mother has contributed all that much to the breakdown of Western civilization. ${ }^{29}$

Quayle was undeterred. In a speech shortly thereafter to a Southern Baptist Convention meeting in Indianapolis, Quayle did not back down; he doubled down. Of the critics of his complaints about Murphy Brown, he said, "I wear their scorn as a badge of honor." ${ }^{30}$ In the same speech, Quayle hammered away at abortion, gay parents, and sex education in elementary schools. "The changes in our culture in recent decades," he said, have "created a cultural divide in our country." 31 So great was this divide that "it sometimes seems we have two cultures, the cultural elite and the rest of us." ${ }^{\prime 32}$

Quayle appealed directly to the identity politics and cultural resentments of social and religious conservatives. "Talk about right and wrong," Quayle said,

26. Dan Quayle, Vice President of the U.S., Address to the Commonwealth Club of California (May 19, 1992), available at http://www.vicepresidentdanquayle.com/speeches StandingFirm_CCC_3.html [https://perma.cc/2JU4-5KC9].

27. $I d$.

28. Jacey Fortin, That Time 'Murphy Brown' and Dan Quayle Topped the Front Page, N.Y. TiMEs (Jan. 26, 2018), https://www.nytimes.com/2018/01/26/arts/television/murphy-brown-danquayle.html [https://perma.cc/WWF4-F6DM].

29. Laura Bradley, A Murphy Brown Reboot Might Actually Be Perfect for 2018, VANITY FAIR (Jan. 25, 2018), https://www.vanityfair.com/hollywood/2018/01/murphy-brown-reboot-cbs [https://perma.cc/H2Q7-QLC7].

30. Andrew Rosenthal, Quayle Attacks a 'Cultural Elite,' Saying It Mocks Nation's Values, N.Y. Times (June 10, 1992), https://www.nytimes.com/1992/06/10/us/1992-campaign-quayleattacks-cultural-elite-saying-it-mocks-nation-s-values.html [https://perma.cc/SPV9-QLEK].

31. Id.

32. Id. 
"and they'll try to mock us in newsrooms, sitcom studios and faculty lounges across America. But in the heart of America, in the homes and workplaces and churches, the message is heard." 33 Quayle denounced the "cultural elite" for "handing out condoms in the schools, or distributing sexual propaganda to our third and fourth graders." ${ }^{\text {"34 }}$ Referring to abortion, he said, "[t]hey treat God's greatest gift, new life, as an inconvenience to be discarded." ${ }^{35}$

Quayle also touched gay and lesbian rights and the newly emerging issue of marriage equality for same-sex couples. Cultural elites, he said, "seem to think the family is an arbitrary arrangement of people who decide to live under the same roof, that fathers are dispensable and that parents need not be married or even of opposite sexes. They are wrong."

The Bush/Quayle ticket would lose that November to Democrats Bill Clinton and $\mathrm{Al}$ Gore. Afterward, Quayle pretty much disappeared from public life.

\section{MIKE PENCE}

Michael Richard Pence was born in Columbus, Indiana, and graduated from Hanover College and, like Quayle, from the IU School of Law in Indianapolis. ${ }^{37}$ He twice ran for Congress unsuccessfully, took a job as head of a conservative think tank called the Indiana Policy Review Foundation, and in 1992 began hosting a political talk radio show that eventually aired on eighteen stations around the state. ${ }^{38}$ In 2000, he finally won his long-sought seat in Congress from Indiana's Second (later renumbered as the Sixth) Congressional District. ${ }^{39}$

In Congress, "Pence aligned himself immediately with the conservative bloc and sought to apply the media skills he had honed over seven years" as a talk radio host. ${ }^{40}$ In what seems today like unlikely praise from a surprising place, Pence was named by Esquire magazine in 2008 as one of the 10 best members of Congress. "From immigration to earmarks," the magazine wrote, "Pence is one of the most principled members, from either party, and his unalloyed traditional conservatism has repeatedly pitted him against his party elders. ${ }^{41}$

When Quayle denounced same-sex marriage in 1992, same-sex couples raising children together were just beginning to emerge into public awareness, and legal same-sex marriage was considered by most people to be a truly far-out

\section{Id.}

34. Id.

35. Id.

36. Id.

37. Andrea Neal, Pence: The Path to Power 2, 14, 24 (2018).

38. Id. at $46-57,76$.

39. For an excellent biography of Pence's Indiana upbringing and political life before becoming vice president, see generally NEAL, supra note 37.

40. NEAL, supra note 37, at 121.

41. The 10 Best Members of Congress, EsQUIRE (Oct. 15, 2008), https://www.esquire.com/ news-politics/a5110/10-best-members-congress-text/ [https://perma.cc/QZR6-922S]. 
idea. ${ }^{42}$ But social attitudes toward gay and lesbian relationships evolved rapidly. While Pence was and is conservative across the board - what Kellyanne Conway has called a "full-spectrum conservative" ${ }^{43}$ - he became associated, both as a congressman and as governor, with vigorous opposition to the rapidly emerging, rapidly mainstreaming movement for gay and lesbian rights. ${ }^{44}$

As a congressman, Pence opposed any effort to recognize gays and lesbians as a minority group entitled to the protection of federal anti-discrimination laws similar to the protections extended to women and racial and ethnic minorities. ${ }^{45}$ Regarding federal AIDS funding under the Ryan White Care Act, Pence called for "an audit to ensure that federal dollars were no longer being given to organizations that celebrate and encourage the types of behaviors that facilitate the spreading of the HIV virus," and instead advocated for resources to be directed toward institutions "which provide assistance to those seeking to change their sexual behavior." ${ }^{46}$ This remark has been interpreted as support by Pence for anti-gay "conversion therapy." 47

Pence opposed allowing gays to serve in the military, said being gay was a choice, and warned that "societal collapse was always brought about following an advent of the deterioration of marriage and family." 48 He favored a federal constitutional amendment that would have taken the extraordinary step of banning same-sex marriage nationwide. ${ }^{49}$

With an eye toward someday running for president and believing he needed executive experience, Pence successfully ran for governor of Indiana in 2012. ${ }^{50}$

42. Karen De Witt, THE 1992 CAMPAIGN: The Vice President; Quayle Contends Homosexuality is a Matter of Choice, Not Biology, N.Y. Times (Sept. 14, 1992), https://www. nytimes.com/1992/09/14/us/1992-campaign-vice-president-quayle-contends-homosexuality-matterchoice-not.html [https://perma.cc/WM5H-QTBW].

43. Jane Mayer, The Danger of President Pence, New Yorker (Oct. 23, 2017), https://www.newyorker.com/magazine/2017/10/23/the-danger-of-president-pence [https://perma.cc/93RJ-78VK].

44. NeAL, supra note 37, at 164-88.

45. The position statement appears on an archived version of one of Pence's congressional campaign websites, The Pence Agenda for the 107th Congress: A Guide to Renewing the American Dream, http://web.archive.org/web/20010519165033fw_/http:/cybertext.net/pence/issues.html [https://perma.cc/BRB9-3B9H] (last visited Mar. 24, 2019).

46. Id.

47. Liam Stack, Mike Pence and 'Conversion Therapy': A History, N.Y. Times (Nov. 30, 2016), https://www.nytimes.com/2016/11/30/us/politics/mike-pence-and-conversion-therapy-ahistory.htmlhttps:/www.nytimes.com/2016/11/30/us/politics/mike-pence-and-conversion-therapya-history.html [https://perma.cc/QTA3-YJ56].

48. Will Drabold, Here's What Mike Pence Said on LGBT Issues Over the Years, TIME (July 15, 2016), http://time.com/4406337/mike-pence-gay-rights-lgbt-religious-freedom/ [https://perma. cc/3DC6-TJC5].

49. Id.

50. See generally Michael D'Antonio, Mike Pence's Plan to Outlast Trump, CNN (Aug. 30, 2018), https://www.cnn.com/2018/08/28/opinions/mike-pence-plan-to-outlast-trump-dantonio- 
It is generally agreed that the most difficult period of his term was the controversy over Indiana's Religious Freedom Restoration Act ("RFRA"), which was approved by the General Assembly in $2015 .{ }^{51}$ Pence embraced the RFRA, signing it in a ceremony crowded with religious leaders and defending it in a widely panned appearance on national television. ${ }^{52}$ The RFRA was intended to allow citizens and businesses to challenge laws that burdened their freedom of religious exercise. ${ }^{53}$ In that sense, it was not specifically an "anti-gay law." But as a practical matter, it was understood as potentially giving legal cover to allow religiously conservative business owners, especially wedding service providers, to refuse to serve gays and lesbians. ${ }^{54}$ Indiana had no statewide law prohibiting anti-LGBT discrimination, but most significant cities in the state do have such ordinances. ${ }^{55}$ The RFRA was understood as potentially giving business owners who opposed LGBT rights an excuse not to comply with such ordinances.

A few years earlier, the issue might not have gotten as much attention. But in 2015, same-sex marriage was on a roll. Same-sex marriage had been legalized in Indiana just the previous fall by federal court order. ${ }^{56}$ Through a sort of perfect storm of rising national sympathy with LGBT rights and declining support for religion (or at least increased skepticism toward religiously based politics), Indiana's RFRA quickly became not just a state controversy, but a national one. ${ }^{57}$ As I wrote in a blog post at the time, the RFRA became toxic because pretty much everyone knew it was "impelled by the politics of anti-gay backlash." RFRA's most ardent supporters were Christian conservative activists who resented or feared the nation's sea change on LGBT rights. ${ }^{59}$

In an attempt to quell the furor, especially from the state's business community, legislators amended the RFRA to specify that it could not be used to

eisner/index.html [https://perma.cc/785Q-8NC6].

51. One biographer refers to the RFRA controversy as "the single biggest crisis of Pence's tenure as governor." NEAL, supra note 37, at 177.

52. Id. at 176 .

53. See generally Dwight Adams, RFRA: Why the 'Religious Freedom Law' Signed by Mike Pence Was So Controversial, IndianaPOLIS STAR (Apr. 25, 2018), https://www.indystar.com/ story/news/2018/04/25/rfra-indiana-why-law-signed-mike-pence-so-controversial/546411002/ [https://perma.cc/NHW8-LPJ2].

54. Id.

55. See Stephanie Wang, A List of Local LGBT Anti-discrimination Ordinances in Indiana, INDIANAPOLIS STAR (Sept. 23, 2015), https://www.indystar.com/story/news/politics/2015/09/23/alist-of-local-lgbt-anti-discrimination-ordinances-in-indiana/72627926/ [https://perma.cc/U4ZJVV4J].

56. See generally Baskin v. Bogan, 766 F.3d 648 (7th Cir. 2014).

57. See generally Adams, supra note 53.

58. Steve Sanders, Indiana's RFRA: The Law is Complicated, But the Anti-Gay Politics Are Not, AM. CONST. SOC'Y BLOG (Mar. 29, 2015), https://www.acslaw.org/acsblog/indianas-rifra-thelaw-is-complicated-but-the-anti-gay-politics-are-not/ [https://perma.cc/BJ3N-2U2U].

59. See generally Adams, supra note 53. 
challenge any non-discrimination law or ordinance, and Pence signed the amendment into law. ${ }^{60}$ Pence then took flak from religious conservatives. One email sent to the governor's office complained that "Indiana is fronted by a coward." 61

Why did Pence — a skillful politician in most people's assessment—stumble so badly during the RFRA controversy? Indianapolis Star political columnist Matt Tully offered an insightful analysis of that question, arguing that Pence's skills, style, and temperament were better suited to being a legislator than to being the leader of an executive branch. "Pence," wrote Tully, "was never meant to be a governor. A partisan and dysfunctional Congress that lives on bright line divisions was his home for 12 years, and that's where he belongs - in a place where a person can rise high by talking well and digging in and not really doing much." ${ }^{62}$ Pence "thrived while representing a gerrymandered congressional district, one where he could safely walk an ideological line and live largely in a partisan bubble. He has failed to understand that a governor's job is to represent a much more diverse state." ${ }^{63}$ Being governor, Tully said, is "about being a leader who is forced every day to think pragmatically, who knows that doing no harm is high on the list of requirements." ${ }^{\prime 64}$

Despite a rocky term as governor that hurt his image nationally, Pence found himself in 2016 on a presidential ticket with Donald Trump. ${ }^{65}$ It seems clear that Pence, like Quayle, was chosen in large measure because of his appeal to social and religious conservatives, a bloc that has only grown in power within the GOP. As The Atlantic observed, "[e]vangelical leaders across the country point to Pence's record on abortion and religious freedom and liken him to a prophet restoring conservative Christianity to its rightful place at the center of American life." ${ }^{66}$ Richard Land, the president of the Southern Evangelical Seminary and one of Trump's "faith advisers," praised Pence as "the 24-karat-gold model of what we want in an evangelical politician. I don't know anyone who's more consistent

60. Tony Cook \& Brian Eason, Gov. Mike Pence Signs RFRA Fix, Indianapolis STAR (Apr. 1, 2015), https://www.indystar.com/story/news/politics/2015/04/01/indiana-rfra-deal-sets-limitedprotections-for-lgbt/70766920/ [https://perma.cc/23DL-TNZ7].

61. Brian Slodysko, Emails: Conservatives Slammed Then-Gov. Mike Pence in 2015 for Changing Religious Freedom Law, INDIANAPOLIS STAR (Mar. 28, 2018), https://www.indystar.com/ story/news/politics/2018/03/28/emails-conservatives-slammed-then-gov-mike-pence-2015changing-religious-freedom-law/467254002/ [https://perma.cc/JQ2D-CT2Z].

62. Matthew Tully, Mike Pence is Out of His League as Governor, INDIANAPOLIS STAR (Apr. 1, 2015), https://www.indystar.com/story/opinion/columnists/matthew-tully/2015/03/31/tully-mikepence-league-governor/70746540/ [https://perma.cc/2QUA-BLMH].

63. Id.

64. Id.

65. Mayer, supra note 43.

66. McKay Coppins, God's Plan for Mike Pence, Atlantic (Jan./Feb. 2018), https://www. theatlantic.com/magazine/archive/2018/01/gods-plan-for-mike-pence/546569/ [https://perma.cc/4NCA-2BR2]. 
in bringing his evangelical-Christian worldview to public policy." ${ }^{97}$

In Dan Quayle's time as vice president, social and religious conservatives were one constituency among many in the Republican Party which had to be kept happy, or at least compliant, but they did not define the party the way they do now. Today, the Christian evangelical base pretty much is the Republican Party. As former Trump strategist Steve Bannon told New Yorker writer Jane Mayer for a Pence profile last fall, Pence is "the outreach guy, the connective tissue" between the Trump Administration and the most conservative wing of the Republican establishment. ${ }^{68}$ "Trump's got the populist nationalists," Bannon said. "But Pence is the base. Without Pence, you don't win." "has the political experience, the connections, the discipline, and the ideological mooring that Trump lacks." ${ }^{\prime \prime 0}$

So, what does the future hold for Mike Pence? Many people assume he would still like to be president. A debate has emerged among some political observers about whether a President Pence would be preferable to President Trump. Some, like Washington Post columnist Dana Milbank, have made the case that Pence would be better: "Pence is, at core, a small-d democrat, not a demagogue. The world would be safer with him in charge." "11 Others, like the recently departed White House aide Omarosa Newman, have said no. "We would be begging for days of Trump back if Pence became president, that's all I'm saying," Newman told a journalist. " "He's extreme. I'm Christian. I love Jesus. But he thinks Jesus tells him to say things. I'm like, 'Jesus ain't saying that."'73

Despite his aw-shucks image, Pence is a savvy politician who has always taken "a calculated approach to his political career." ${ }^{\text {"74 }}$ Pence's underappreciated subtlety and complexity were captured by journalist McKay Coppins in a profile for The Atlantic. In it, Coppins describes a scene where the new Vice President Pence is returning to a hero's welcome in front of a friendly crowd at an Anderson, Indiana, factory.

When the time comes, Pence takes the stage and greets the crowd with

67. Id

68. Mayer, supra note 43.

69. Id.

70. Id.

71. Dana Milbank, 'President Pence' Is Sounding Better and Better, WASH. Post (June 6, 2017), https://www.washingtonpost.com/opinions/president-pence-is-sounding-better-andbetter/2017/06/06/c1bf0f52-4af3-11e7-9669-250d0b15f83b_story.html?utm_term=.16c7c50218ec [https://perma.cc/MTU7-4B76].

72. Helena Andrews-Dyer, Omarosa on Mike Pence: 'He Thinks Jesus Tells Him to Say Things,' WASH. Post (Feb. 12, 2018), https://www.washingtonpost.com/news/reliable-source/wp/ 2018/02/12/omarosa-on-mike-pence-he-thinks-jesus-tells-him-to-say-things/?utm _ term=.b51e43aa762a [https://perma.cc/PLG9-A2CS].

73. Id.

74. NEAL, supra note 37 , at 228. 
a booming "Hellooooo, Indiana!" He says he has "just hung up the phone" with Donald Trump and that the president asked him to "say hello."

He delivers this message with a slight chuckle that has a certain, almost subversive quality to it. Watch Pence give enough speeches, and you'll notice that this often happens when he's in front of a friendly crowd.

He'll be witnessing to evangelicals at a mega-church, or addressing conservative supporters at a rally, and when the moment comes for him to pass along the president's well-wishes, the words are invariably accompanied by an amused little chuckle that prompts knowing laughter from the attendees.

It's almost as if, in that brief, barely perceptible moment, Pence is sending a message to those with ears to hear-that he recognizes the absurdity of his situation; that he knows just what sort of man he's working for; that while things may look bad now, there is a grand purpose at work here, a plan that will manifest itself in due time. Let not your hearts be troubled, he seems to be saying. I've got this."

It may be a cliché that only God knows what the future has in store for Mike Pence. Suffice it to say that, as of the time of this symposium, it remains to be seen whether Pence's time as vice president will be remembered, like Dan Quayle's, as dutiful but undistinguished, or as a more remarkable adventure by a son of the Hoosier state.

75. Coppins, supra note 66. 